\title{
A Simple Field Technique for Identification of Some Sagebrush Taxa
}

\section{RICHARD STEVENS AND E. DURANT MCARTHUR}

Highlight: A technique has been developed that provides an on-the-spot field test to aid in identification of some sagebrush taxa. Seeds, dried or green crushed leaf material, or stem cambium of various sagebrush taxa will produce distinctive shades of blue when wet and placed under longwave ultraviolet light. The technique is particularly helpful in separation of Artemisia tridentata subsp. tridentata from A. tridentata $s u b s p$. vaseyana. Subspecies vaseyana extracts are blue, whereas those of subsp. tridentata are not. All taxa producing blue water extracts are preferred by mule deer.

Recent observations have demonstrated that palatability on winter ranges of some sagebrush taxa relates closely to chromatographic patterns (Hanks et al., 1971, 1973; Hanks and Jorgensen, 1973). Taylor et al. (1964)

The authors are game biologist, Utah Division of Wildlife Resources, Ephraim Utah, and research geneticist, U.S. Department of Agriculture, Forest Service, Inter mountain Forest and Range Experiment Station, Ogden, Utah, stationed in Ephraim.

Federal aid in wildlife restoration funds was provided through Project W-82-R.

The use of trade, firm, or corporation names in this publication is for the information and convenience of the reader. Such use does not constitute an official endorsement or approval by the Utah Division of Wild life Resources and the U.S. Department of Agriculture of any product or service to the exclusion of others which may be suitable.

The authors thank the members of Botany and Range Science Department of Brigham Young University, Provo, Utah, and the Chemistry Department of Snow College, Ephraim, Utah, for use of their equipment and materials.

Manuscript received February 19, 1974. noted the differential fluorescence in moist seeds of Artemisia tridentata subsp. tridentata and subsp. vaseyana under ultraviolet light. Subspecies vaseyana seeds fluoresce and subsp. tridentata seeds do not. We have observed that different shades of blue are apparent in various sagebrush taxa immediately after application of water under longwave ultraviolet light (e.g., black light lamps M-16 for use in the field or UV-21 for laboratory use from Ultraviolet Products Inc., San Grabriel, Calif.). This test is effective on fresh or dried material (crushed leaves, seeds, or broken stems) any time of the year.

Because of the tcchnique's simplicity and ease of use, it should prove useful for identifying sagebrush taxa. Taxa cannot be distinguished solely by color differences of water extract, but the color differences conveniently dovetail, so that taxa most likely to be confused on the basis of morphological criteria are in different color groups (Table 1); e.g., the subspecies of big sagebrush (A. tridentata). Subspecies tridentata extracts show little color, whereas those of subsp. vaseyana are an intense blue. The third subspecies, wyomingensis, is recognized by a light-blue water extract.
Extracts of a larger statured ecotype of subsp. wyomingensis from northcentral Nevada (Brunner, 1972) show more blue than those of subsp. wyomingensis collections from western Wyoming. Artemisia tridentata subsp. tridentata and $A$. tridentata subsp. wyomingensis cannot always be separated by the color test, but the short stature and spatulate leaves of the latter subspecies contrast with the taller stature and narrow leaves of subsp. tridentata.

Color extracts are helpful in identifying some palatable species and ecotypes; e.g., two forms of $A$. nova have been identified (Tables 1 and 2) and designated as forms (a) and (b). Artemisia nova (a) tends to be more palatable and produces a bluer extract than $A$. nova (b). Beetle (1960) and Winward and Tisdale (1969) also noted two forms of $A$. nova.

High preference is shown by mule deer for all taxa producing blue extracts. The intensity of the blue can be taken as a palatability indicator with two notable exceptions: $A$. tridentata subsp. wyomingensis, which exhibits little color, is highly palatable and $A$. bigelovii, which lacks color, is also palatable.

Table 1. Qualitative water soluble extract color groups of some Tridentatae taxa.

\begin{tabular}{lll}
\hline \hline Intense blue & Light blue & Pale blue to colorless \\
\hline A. arbuscula & A. cana & A. bigelovii \\
A. longiloba & A.rigida & A.nova (b) \\
A. nova (a) & A. tridentata wyomingensis & A. tridentata tridentata \\
A. rothrockii & A. tripartita & \\
A. tridentata vaseyana & & \\
\hline
\end{tabular}


Table 2. Quantitative water extract differences of six sagebrush taxa as determined with a spectrophotometer. Low percent transmittance indicates blue extract. Data are from foliar material.

\begin{tabular}{lccc}
\hline & \multicolumn{2}{c}{ Percent transmittance } & Number of \\
\cline { 2 - 3 } Taxa & Mean & Range & $\begin{array}{c}\text { Numbessions } \\
\text { accenn }\end{array}$ \\
\hline A. nova (b) & $43 \mathrm{ab}$ & $31-49$ & 4 \\
A. tridentata tridentata & $41 \mathrm{ab}$ & $29-55$ & 15 \\
A. tridentata wyomingen sis & $33 \mathrm{~b}$ & $30-38$ & 6 \\
A. nova $(\mathrm{a})$ & $18 \mathrm{c}$ & $12-25$ & 5 \\
A. tridentata vaseyana & $12 \mathrm{c}$ & $6-18$ & 13 \\
A. longiloba & $5 \mathrm{~d}$ & $4-5$ & 3 \\
\hline
\end{tabular}

${ }^{1}$ Means followed by the same two letters are not significantly different, those sharing only one common letter are significantly different at the $\mathbf{5} \%$ level, and those sharing no common let ters are significantly different at the $1 \%$ level.

When a color difference in leaf extract is not discernible and a difference in palatability exists between or within taxa, a wet cambium usually exhibits a color difference.

In order to quantify and test significance of color differences of certain sagebrush taxa, some standard laboratory procedures were employed. Foliar material from about 50 widely occurring accessions of Tridentatae was collected. A mortar and pestle was used to pulverize air-dried foliar material. A 100-mg sample was mixed with $50 \mathrm{ml}$ of distilled water, shaken for 30 sec, allowed to extract for an additional $2-1 / 2 \mathrm{~min}$, and filtered through
Whatman No. 4 filter paper. The percent of light transmittance of the filtrate was measured with a Beckman Spectronic 20 Spectrophotometer at $364 \mathrm{~m} \mu$. An analysis of variance test was employed to determine whether significant color differences occur between Artemisia taxa. Quantitative color differences between taxa are shown on Table 2.

Comparison of two-dimensional chromatograms of both water- and alcohol-soluble extracts of foliar material indicated that the blue compounds are principally the coumarin derivatives and their glycosides described by Shafizadeh and Melnikoff (1970).

\section{Literature Cited}

Beetle, A. A. 1960. A study of sagebrush, the section Tridentatae of Artemisia. Univ. Wyo. Agr. Exp. Sta. Bull. 368. $83 \mathrm{p}$.

Brunner, J. R. 1972. Observations on Artemisia in Nevada. J. Range Manage. $25: 205-208$.

Hanks, D. L., J. R. Brunner, D. R. Christensen, and A. P. Plummer. 1971. Paper chromotography for determining palatability differences in various strains of big sagebrush. Forest Serv., U. S. Dep. Agr. USDA Forest Serv. Res. Pap. INT-101. 9 p.

Hanks, D. L., and K. R. Jorgensen. 1973. Chromatographic identification of big sagebrush seed. J. Range Manage. 26:304.

Hanks, D. L., E. D. McArthur, R. Stevens, and A. P. Plummer. 1973. Chromatographic characteristics and phylogenetic relationships of Artemisia, section Tridentatae. Forest Serv., U. S. Dep. Agr. USDA Forest Serv. Res. Pap. INT141. $24 \mathrm{p}$.

Shafizadeh, F., and A. B. Melnikoff. 1970. Coumarins of Artemisia tridentata ssp. vaseyana.. Phy tochemistry 9:1311-1316.

Taylor, R. L., L. S. Marchand, and C. W. Crompton. 1964. Cytological observations on the Artemisia tridentata (Compositae) complex in British Columbia. Can. J. Genet. Cytol. 6:42-45.

Winward, A. H., and E. W. Tisdale. 1969. A simplified chemical method for sagebrush identification. Forest Serv., U. S. Dep. Agr., Intermountain Region. Range Improv. Notes 14(3):1-4. 